\title{
PERBEDAAN BENTUK DAN UKURAN RUGAE PALATINA ANTARA MAMAK DAN \\ KAMANAKAN LAKI-LAKI SUKU MINANGKABAU DI WILAYAH LUHAK NAN TIGO
}

\author{
Ovy Prima Damara ${ }^{1}$, Nila Kasuma ${ }^{1}$, dan Eni Rahmi ${ }^{1}$ \\ ${ }^{1}$ Mahasiswa Fakultas Kedokteran Gigi Universitas Andalas \\ ${ }^{2}$ Staf Fakultas Kedokteran Gigi Universitas Andalas \\ ${ }^{2}$ Staf Fakultas Kedokteran Gigi Universitas Andalas
}

\begin{abstract}
ABSTRAK
Forensic odontology in dentistry is used to identify victims. Several methods can be used, such as rugoscopy. Rugoscopy is a victim identification method by evaluating the palatal rugae. Rugoscopy is very advantageous due to its low cost, fast results and practical nature. Palatal rugae is protected from trauma and high temperature due to its internal position in the oral cavity. Palatal rugae is an individualistic structure, though it bears several resemblance with the hereditary pattern due to the polygenic mechanism. The purpose of this research is to determine the difference of palatal rugae shape and size between uncle and nephew in Minangkabau ethnics. This study is an analytical observational study with a cross sectional approach. A total of 78 pairs of uncle and nephew of the Minangkabau ethnicity in Luhak Nan Tigo. Palatal rugae is classified using the Thomaz and Khutze classification. Data were analyzed by using Mann Whitney non-parametric statistical analysis. Data analysis show the palatal rugae shape of uncle and nephew from the Minangkabau ethnicity is dominated by a wavy shape, followed by curvy, straight, unified and circular shapes. The palatal rugae size of uncle and naphew from the Minangkabau ethnicity is dominated by primary size, followed by secondary and fragmenter size. Mann Whitney analysis revealed no significant difference of palatal rugae shape and size between uncle and nephew in Minangkabau ethnics ( $p>0,05)$, though there is a significant difference in the unified shape $(p<0,05)$. Palatal rugae shape and size have a similar pattern with hereditery patterns, though not identical. Palatal rugae may be used as a secondary method of victim identification
\end{abstract}

Keywords : Rugoscopy, palatal rugae, uncle and nephew

Affiliasi penulis : 1. Fakultas Kedokteran Gigi Universitas Andalas,

Korespondensi: Ovy Prima Damara, email: ovyprima@yahoo.com

\section{PENDAHULUAN}

Odontologi forensik adalah ilmu di kedokteran gigi yang terkait dalam suatu data penyidikan untuk mengetahui identitas korban bencana massal seperti kecelakaan pesawat terbang, gempa bumi, tsunami, tindakan kriminal, kebakaran, kecelakaan lalu lintas, dan digunakan untuk kepentingan proses peradilan. ${ }^{1}$ Gigi geligi digunakan dalam odontologi forensik karena mempunyai sifat individualistik sehingga dimasukkan kedalam salah satu metode identifikasi primer pada Disaster Victim Investigation (DVI) selain menggunakan sidik jari dan deoxyribose-nucleiv acid (DNA). Gigi geligi digunakan karena masih bertahan lama sedangkan sidik jari mempunyai keterbatasan. Sidik jari tidak bisa digunakan apabila tangan korban hangus dan putus, sehingga tidak dapat 
digunakan untuk identifikasi korban.,3 Metode lain yang digunakan untuk proses identifikasi korban melalui gigi geligi yaitu cetakan gigi, radiografi, fotografi, bekas gigitan, cheiloscopy, rugoscopy. ${ }^{4}$

Rugoscopy sebagai salah satu metode identifikasi dalam odontologi forensik merupakan istilah pertama yang diusulkan pada tahun 1932 oleh seorang peneliti spanyol yang bernama Trobo Hermosa. Rugoscopy digunakan untuk mengidentifikasi identitas seseorang dengan menggunakan rugae palatina. Rugae palatina dimiliki setiap individu dengan karakteristik yang unik sehingga dapat memberikan informasi dalam mengidentifikasi seseorang dengan cara pencetakan rugae palatina, tracing, dan pola digital rugae. Analisis bentuk dan ukuran rugae palatina menggunakan klasifikasi Thomaz dan Khutze. Hal ini dikarenakan klasifikasi tersebut sering digunakan pada penelitian dan menggabungkan pola bentuk dan ukuran rugae palatina ${ }^{4,5}$

Rugae palatina biasanya disebut dengan plica palatina tranversal yaitu tonjolan pada bagian mukosa anterior di palatum yang berada diantara median palatal raphe dan dibelakang papila insisivus. Pola rugae palatina juga digunakan untuk bidang ilmu lain seperti antropologi, genetika, prostodontik, dan ortodontik. $^{6} \quad$ Penggunaan rugoscopy dalam odontologi forensik dilakukan karena rugae palatina memiliki karakter individualistik yang berbeda antara satu orang dengan orang lain, hal ini memungkinkan setiap orang memiliki cetakan rugae palatina sebagai data ante mortem dan membandingkan dengan data post mortem pada saat identifikasi korban. $^{7}$ Bentuk rugae palatina selalu stabil dan tidak berubah meskipun seseorang dalam masa pertumbuhan. Disamping itu, penggunaan rugoscopy ini sangat menguntungkan, karena biayanya yang murah, cepat, akurat dan menggunakan teknik yang praktis. ${ }^{5,13}$ Keuntungan lain dari penggunaan rugae palatina pada odontologi forensik adalah ketahanan rugae palatina pada luka bakar derajat tiga dan cadaver yang disimpan pada suhu $5^{\circ} \mathrm{C}$ dengan waktu minimun 7 hari penyimpanan. Didapatkan hasil bahwa bentuk rugae palatina mampu bertahan dengan baik dan tidak terjadi perubahan bentuk yang signifikan. Rugae palatina terlindungi dari trauma dan temperatur yang tinggi karena rugae palatina berada pada posisi internal di rongga mulut dan dikelilingi serta dilindungi oleh bibir, pipi, lidah, gigi, dan tulang. ${ }^{5-8}$ Dalam bidang ortodontik penggunaan alat ortodontik cekat tidak menyebabkan perubahan bentuk dari pola 
rugae palatina. Perubahan yang terjadi hanyalah perubahan struktur tulang selama pemakaian alat ortodontik tersebut. $^{5,8,9}$

\section{Rugoscopy digunakan dalam} odontologi forensik untuk menentukan ras, jenis kelamin dan herediter. ${ }^{4}$ Kapali S dkk (1997) melakukan penelitian untuk melihat perbedaan bentuk rugae palatina antara suku Caucasian dan suku Aborigin di dapatkan hasil bahwa rugae primer pada suku Aborigin lebih besar dibandingkan dengan suku Caucasian. Suku Caucasian lebih cenderung memiliki bentuk rugae palatina lurus dan suku Aborigin cendrung berbentuk gelombang. ${ }^{6}$ Di Indonesia telah dilakukan penelitian oleh Akbar dkk (2014) di Jawa Tengah tentang perbedaan pola dan ukuran rugae antara ras Deutro Melayu dan ras Arab. Hasil penelitian menyatakan bahwa adanya perbedaan pola dan ukuran yang bermakna antara kedua ras tersebut. ${ }^{10}$ Kochar dkk (2015) di India juga telah melakukan penelitian tentang perbandingan antara bentuk rugae palatina pada Saudara kandung yang terdiri dari anak anak yang berumur 5 sampai 15 tahun. Berdasarkan penelitian tersebut didapatkan hasil bahwa 30,89\% berbentuk lengkung, $21,07 \%$ berbentuk garis dan $19,62 \%$ berbentuk lekukanlekukan, sehingga dapat dinyatakan bahwa saudara kandung tidak memiliki bentuk rugae palatina yang sama karena rugae palatina bentuknya unik. ${ }^{12}$

$$
\text { Madhusudan, K dkk (2014) }
$$
melakukan penelitian pada 30 orang tua dan anak kandung di sebuah rumah sakit di India. Hasil penelitian didapatkan bahwa bentuk rugae palatina dari ayah dan ibu terdapat kemiripan dengan bentuk rugae palatina anaknya. Pada penelitian ini dijelaskan bentuk rugae palatina dapat dijadikan salah satu cara untuk mengidentifikasi keturunan seseorang karena adanya kesamaan DNA. $^{11}$

Pada ilmu herediter hubungan mamak dan kamanakan merupakan hubungan herediter generasi ke dua. Pada hubungan herediter, penurunan pola rugae palatina terjadi melalui mekanisme unsur poligen. ${ }^{13}$ Poligen merupakan gengen ganda yang membentuk variasi gen fenotip dominan dan mempengaruhi karakteristik individu salah satunya yakni pola rugae palatina. ${ }^{14,15}$ Pada hubungan herediter generasi kedua terdapat kesamaan pembagian DNA sebanyak 25\% dilihat melalui Aunt/Ucle Testing. ${ }^{16}$ Kesamaan DNA sebanyak 25\% akan mempengaruhi pola rugae palatina dari mamak ke kamanakan. Selain penurunan pola rugae palatina, pada hubugan herediter generasi kedua juga terjadi 
penurunan bentuk anatomi dan karakteristik bagian tubuh lain. Seperti, sidik jari, jejas bibir, ukuran gigi, dan bentuk lengkung gigi. ${ }^{17-19}$ Sampai sekarang ini masih belum ada penelitian yang membahas tentang bentuk dan ukuran rugae palatina pada mamak dan kamanakan. Berdasarkan data diatas penulis berkeinginan untuk meneliti apakah terdapat kesamaan pola rugae palatina pada hubungan herediter generasi ke dua antara mamak dan kamanakan laki laki Suku Minangkabau di wiliayah Luhak Nan Tigo.

\section{METODE}

Penelitian ini adalah penelitian analitik observasional melalui pendekatan cross sectional. Sampel penelitian terdiri dari 78 pasang mamak dan kamanakan laki-laki suku Minangkabau di wilayah Luhak Nan Tigo. Klasifikasi rugae palatina yang digunakan adalah klasifikasi Thomaz dan Khutze. Tahapan pertama penelitian yaitu, sampel diberikan informasi mengenai penelitian, kemudian dilakukan wawancara untuk mengetahui data karakteristik responden sesuai kriteria inklusi dan pemeriksaan klinis rongga mulut sesuai kriteria eklusi. Sampel yang sesuai kriteria inklusi dan eklusi menandatangani informed consent dan dilakukan pencetakan rahang atas selanjutnya dilakukan pengecoran secara langsung dilokasi yang sama dengan pencetakan. Rugae palatina pada coran rahang atas yang sudah keras ditandai dengan pensil 2B yang ujungnya runcing dan diukur menggunakan jangka sorong digital. Analisis data menggunakan Uji statistik non-parametrik Uji Mann Whitney.

\section{HASIL}

Penelitian ini mulai dari tanggal 3 Maret 2017 sampai 12 Maret 2017 di Kecamatan Tanjung Gadang, Kecamatan Guguk, dan Kecamatan Situjuh di Kabupaten 50 Kota; Kecamatan Tanjung Baru dan Kecamatan Pariangan di Kabupaten Tanah Datar; serta Kecamatan Baso di Kabupaten Agam. Sampel penelitian berjumlah 78 pasang sampel yang terdiri dari mamak dan kamanakan laki-laki suku Minangkabau di wilayah Luhak Nan Tigo.

\section{Jumlah pola rugae palatina mamak dan kamanakan laki-laki berdasarkan bentuk}

Tabel 1 Jumlah pola rugae palatina mamak dan kamanakan laki-laki

\begin{tabular}{|c|c|c|c|}
\hline \multirow{2}{*}{$\begin{array}{c}\text { Klasifikasi } \\
\text { Bentuk Rugae } \\
\text { Palatina }\end{array}$} & & \multicolumn{2}{|c|}{ Rata-ratatSD } \\
\hline & 56 & Mamak & Kamanakan \\
\hline Melengkung & & $2,54 \pm 1,93$ & $2,03 \pm 1,48$ \\
\hline Bergelombang & & $3,76 \pm 1,78$ & $3,72 \pm 1,53$ \\
\hline Lurus & & $1,85 \pm 1,81$ & $1,84 \pm 1,69$ \\
\hline Sirkular & & $0,24 \pm 0,56$ & $0,15 \pm 0,45$ \\
\hline Unifikasi & & $0,59 \pm 1,05$ & $1,06 \pm 1,03$ \\
\hline
\end{tabular}


Pola rugae palatina didominasi oleh bentuk bergelombang. Tabel 5.1 menunjukkan jumlah rata-rata pola rugae palatina bentuk bergelombang pada mamak 3,76 11,78 . Sedangkan, jumlah rata-rata pola rugae palatina bentuk bergelombang pada kamanakan laki-laki yaitu $3,72 \pm 1,53$ dan paling sedikit bentuk sirkuler jumlah rata-rata pola rugae palatina bentuk sirkular pada mamak yaitu $0,24 \pm 0,56$ sedangkan jumlah ratarata pola rugae palatina bentuk sirkular pada kamanakan laki-laki yaitu $0,15 \pm 0,45$.

\section{Jumlah pola rugae palatina mamak dan kamanakan laki-laki berdasarkan ukuran}

Tabel 2 Jumlah pola rugae palatina mamak dan kamanakan laki-laki berdasarkan ukuran

\begin{tabular}{|c|c|c|c|}
\hline \multirow{2}{*}{$\begin{array}{c}\text { Klasifikasi } \\
\text { Bentuk } \\
\text { Rugae } \\
\text { Palatina }\end{array}$} & n & \multicolumn{2}{|c|}{ Rata-rata 50} \\
\hline & 156 & Mamak & Kamanakan \\
\hline Primer & & $6,90 \pm 2,83$ & $7,28 \pm 1,83$ \\
\hline Sekunder & & $1,78+2,05$ & $1,42 \pm 1,57$ \\
\hline Fragmenter & & $0,29 \pm 0,66$ & $0,23 \pm 0,73$ \\
\hline
\end{tabular}

Jumlah pola rugae palatina didominasi oleh ukuran primer. Tabel 5.2 menunjukkan jumlah rata-rata pola rugae palatina mamak ukuran primer yaitu $6,90 \pm 2,63$. sedangkan jumlah rata-rata pola rugae palatina kamanakan laki-laki ukuran primer yaitu $7,26 \pm 1,93$. Ukuran Fragmeter memiliki jumlah rata-rata paling sedikit. Jumlah rata-rata pola rugae palatina mamak ukuran fragmenter yaitu $0,29 \pm 0,66$. Sedangkan rata-rata pola rugae palatina kamanakan laki-laki ukuran fragmenter yaitu $0,23 \pm 0,73$.

\section{Perbedaan jumlah pola rugae palatina antara mamak dan kamanakan laki-laki berdasarkan bentuk dan ukuran}

Tabel 3 Perbedaan pola rugae palatina berdasarkan bentuk

\begin{tabular}{|c|c|c|c|c|}
\hline $\begin{array}{c}\text { Klasifikasi } \\
\text { Bentuk } \\
\text { Rugae } \\
\text { Palatina }\end{array}$ & Kelompok & $n$ & $\begin{array}{c}\text { Rata-rata } \\
\text { SD }\end{array}$ & $p$ \\
\hline \multirow[t]{2}{*}{ Melengkung } & Mamak & 78 & $2,54 \pm 1,83$ & 0,24 \\
\hline & Kamanakan & 78 & $2,03 \pm 1,48$ & \\
\hline \multirow{2}{*}{$\begin{array}{l}\text { Bergelom- } \\
\text { bang }\end{array}$} & Mamak & 78 & $3,76 \pm 1,78$ & 0,97 \\
\hline & Kamanakan & 78 & $3,72 \pm 1,53$ & \\
\hline \multirow[t]{2}{*}{ Lurus } & Mamak & 78 & $1,85 \pm 1,81$ & 0,45 \\
\hline & Kamanakan & 78 & $1,94 \pm 1,69$ & \\
\hline \multirow[t]{2}{*}{ Sirkular } & Mamak & 78 & $0,24 \pm 0,56$ & 0,25 \\
\hline & Kamanakan & 78 & $0,15 \pm 0,45$ & \\
\hline \multirow[t]{2}{*}{ Unifikasi } & Mamak & 78 & $0,59 \pm 1,05$ & 0,00 \\
\hline & Kamanakan & 78 & $1,06 \pm 1,03$ & \\
\hline
\end{tabular}

Perbedaan jumlah bentuk pola rugae palatina pada tabel 5.4 menunjukkan $\mathrm{p}>0,05$ pada bentuk melengkung, bentuk bergelombang, bentuk lurus, dan bentuk sirkular berarti tidak terdapat perbedaan yang signifikan kecuali pada bentuk unifikasi rugae 
palatina unifikasi antara mamak dan kamanakan laki-laki memiliki perbedaan.

\section{Perbedaan jumlah pola rugae palatina bedasarkan ukuran}

Tabel 5 Perbedaan jumlah pola rugae palatina bedasarkan ukuran

\begin{tabular}{|c|c|c|c|c|}
\hline $\begin{array}{c}\text { Klasifikasi } \\
\text { panjang } \\
\text { rugae } \\
\text { palatina }\end{array}$ & Kelompok & $\mathbf{n}$ & Mean $\pm S D$ & $\mathbf{p}$ \\
\hline \multirow{2}{*}{ Primer } & Mamak & 78 & $6,90 \pm 2,63$ & \multirow{2}{*}{0,12} \\
\hline & Kamanakan & 78 & $7,26 \pm 1,93$ & \\
\hline \multirow{2}{*}{ Sekunder } & Mamak & 78 & $1,78 \pm 2,05$ & \multirow{2}{*}{0.49} \\
\hline & Kamanakan & 78 & $1,42 \pm 1,57$ & \\
\hline \multirow{2}{*}{ Fragmenter } & Mamak & 78 & $0,29 \pm 0,66$ & \multirow{2}{*}{0.36} \\
\hline & Kamanakan & 78 & $0,23 \pm 0,73$ & \\
\hline
\end{tabular}

Perbedaan jumlah pola rugae palatina antara mamak dan kamanakan laki-laki berdasarkan ukuran dapat dilihat pada tabel 5.5. Ukuran primer, ukuran sekunder dan ukuran fragmenter memiliki nilai $\mathrm{p}>0,05$ berarti tidak terdapat perbedaan yang signifikan pada jumlah ukuran rugae palatina antara mamak dan kamanakan laki-laki suku Minangkabau.

\section{PEMBAHASAN}

\section{Jumlah pola rugae palatina mamak dan kamanakan laki-laki suku Minangkabau berdasarkan bentuk}

Pada penelitian ini, hasil analisis jumlah bentuk rugae palatina mamak dan kamanakan laki-laki suku Minangkabau didominasi bentuk bergelombang. Diikuti rata-rata rugae palatina bentuk melengkung. Kemudian, bentuk lurus, Setelah bentuk lurus, bentuk unifikasi sedikit ditemukan. Hasil ini sejalan dengan penelitian Hidayani (2016) mengenai perbandingan pola rugae palatina antara 30 ibu kandung dan 30 anak kandung suku Minang yang mempunyai rata-rata bentuk bergelombang lebih banyak. Hal ini disebabkan sampel penelitian lebih sedikit. Pada masa embrional, perempuan mengalami evolusi regresif yang lebih jelas bandingkan laki-laki sehingga mempengaruhi pembentukan jumlah pola awal rugae palatina yang didominasi bentuk bergelombang dan bersifat stabil. $^{6,20}$

Penelitian ini sejalan dengan penelitian Patel (2015) pada orangtua dan anak kandung didapatkan bahwa jumlah bentuk bergelombang pada ibu sama dengan jumlah bentuk bergelombang pada anak tetapi jumlah bentuk bergelombang pada ayah lebih sedikit daripada jumlah bentuk bergelombang pada anak. ${ }^{21}$ Penelitian ini sejalan dengan penelitian Indira (2012) pada anak kembar didapatkan bahwa bentuk bergelombang dan melengkung sangat mendominasi dan memiliki jumlah ratarata tidak jauh berbeda. ${ }^{22}$

Kesamaan ras mempengaruhi jumlah bentuk rugae palatina. Hal ini sejalan dengan penelitian penelitian penelitian Pratiwi (2016) mengenai 
bentuk pola rugae palatal suku Minang pada 61 sampel laki-laki dan perempuan di SMKN 2 Pariaman menunjukkan hasil bahwa laki-laki suku Minangkabau menunjukkan jumlah nilai rata-rata sebesar 3,82 pada bentuk bergelombang, 2,18 pada bentuk melengkung, 1,85 pada bentuk lurus, 1,34 pada bentuk unifikasi dan bentuk sirkuler memiliki rata-rata paling kecil yakni sebesar 0,74.23 Penelitian Anggraini (2013) mengenai perbedaan bentuk rugae palatina pada 62 sampel penelitian yang berasal dari ras Deutro Melayu dan ras Cina di Jawa Tengah. Pada ras Deutro Melayu rugae palatina didominasi oleh bentuk bergelombang, sedangkan pada ras Cina rugae palatina di dominasi oleh bentuk lurus. $^{24}$

Bentuk rugae palatina mamak dan kamanakan laki-laki suku Minangkabau menunjukkan tingkatan jumlah bentuk rugae palatina sejalan dengan penelitian Hidayani (2016), Patel (2015), dan Indira (2012) karena mamak dan kamanakan laki-laki merupakan hubungan herediter. Pada hubungan herediter jumlah pola rugae palatina diturunkan dengan jumlah yang hampir sama. Mamak dan kamanakan laki-laki memiliki ras yang sama yaitu ras deutro melayu, kesamaan ras akan mempengaruhi bentuk dan ukuran rugae palatina karena memiliki kesamaan gaya hidup, perilaku, makanan yang dikonsumsi ${ }^{24,25}$

\section{Jumlah pola rugae palatina mamak dan kamanakan laki-laki suku Minangkabau berdasarkan ukuran}

Pada penelitian ini, hasil analisis jumlah ukuran rugae palatina mamak dan kamanakan laki-laki suku Minangkabau di dominasi oleh ukuran primer. Selanjutnya, ukuran sekunder dan ukuran yang jarang ditemukan yaitu ukuran fragmenter. Hasil peneltian ini sejalan dengan penilitian Kamala (2011) tentang ukuran rugae palatina orang tua dan anak kandung. Didapatkan hasil rugae primer memiliki jumlah yang paling banyak sebanyak 49,3\% dan paling sedikit yakni rugae fragmenter sebanyak 10,01\%.26 Hasil penelitian sejalan dengan penelitian Hasil penelitian ini sejalan dengan penelitian Aditana (2015) mengenai perbedaan ukuran rugae palatina antara 50 laki-laki dan 50 perempuan ras Deutro Melayu dengan ras Australoid di Jawa Tengah. Hasil penelitian menunjukkan bahwa ukuran primer pada laki-laki ras Deutro Melayu memiliki frekuensi yang lebih banyak yakni 1,331 dan ukuran fragmenter memiliki jumlah rata-rata yang paling sedikit yakni 0,902.27 Muhasilovic (2016) melakukan penelitian mengenai perbedaan rugae palatina antara 250 laki-laki dan 250 perempuan yang berusia 35 tahun di Bosnia dan 
Herzegovina didapatkan hasil bahwa jumlah rata-rata ukuran rugae primer pada laki-laki sebesar 5,31 sedangkan rata-rata ukuran rugae sekunder pada laki-laki 0,47 dan rugae fragmenter memiliki jumlah rata-rata sebesar $0,02 .^{28}$

Laki-laki memiliki ukuran bentuk anatomi tubuh seperti bentuk wajah, bentuk kepala, ukuran gigi, ukuran tulang maksila, dan otot tubuh yang lebih besar dibandingkan perempuan. ${ }^{29}$ Berdasarkan ukuran anatomi, ukuran rahang laki-laki dan lengkung rahang laki-laki lebih besar dari pada perempuan sehingga mempengaruhi ukuran rugae palatina pada saat terjadi penebalan jaringan dibagian anteroposterior palatum.29,30 Hal ini menyebabkan laki-laki sedikit memiliki jumlah rugae sekunder dan fragmenter dibandingkan jumlah rugae primer. Hal ini sejalan dengan penelitian Copra (2013) mengenai hubungan ukuran rugae palatina antara laki-laki dan perempuan dengan lengkung rahang antara laki-laki dan perempuan di India. Didapatkan hasil bahwa rata-rata ukuran rugae palatina primer pada laki-laki memiliki rata-rata lebih besar dibandingkan ukuran primer pada perempuan. Ukuran sekunder pada lakilaki memiliki rata-rata lebih kecil daripada ukuran sekunder pada perepuan. Hal ini sebanding dengan ukuran lengkung rahang laki-laki yang lebih besar daripada lengkung rahang perempuan. $^{31}$

3. Perbedaan jumlah bentuk dan ukuran pola rugae palatina antara mamak dan kamanakan laki-laki suku Minangkabau

Pada penelitian ini jumlah bentuk pola rugae palatina antara mamak dan kamanakan laki-laki bentuk melengkung, bergelombang, lurus dan sirkular memiliki nilai $(p>0,05)$ berarti tidak memiliki perbedaan yang signifikan. Sedangkan, bentuk unifikasi memliki nilai $(\mathrm{p}<0,05)$ berarti terdapat perbedaan yang signifikan. Hal ini sejalan dengan penelitian Hidayani (2016) yang dilakukan pada 48 pasang ibu kandung suku Minang dan anak kandung menunjukkan nilai $\mathrm{p}>0,05$ pada bentuk lurus, sirkular dan melengkung. Bentuk unifikasi tidak terdapat perbedaan ataupun kesamaan, karena penelitian Hidayani (2016) tidak menggunakan klasifikasi Thomaz dan Khutze.20 Penelitian Mahdhsudan (2014) dilakukan pada 30 pasang orang tua dan anak kandung suku Indian menunjukkan nilai korelasi 0,153 antara ayah kandung dan anak dan nilai korelasi 0,198 antara ibu kandung dan anak. Hal ini menunjukkan adanya hubungan yang signifikan dalam bentuk pola rugae palatina pada hubungan herediter. ${ }^{11}$ 
Pada bentuk unifikasi, terdapat perbedaan yang signifikan antara mamak dan kamanakan laki-laki. Pada hubungan herediter bentuk unifikasi tidak selalu diturunkan, Hal ini sejalan dengan penelitian Patel (2015) pada orang tua dan anak kandung, menunjukkan hasil 0,010 pada penurunan bentuk unfikasi dari ayah ke anak kandung.21 Hal ini sejalan dengan penelitian yang dilakukan Kamala (2011) mengenai penggunaan rugae palatal dalam identifikasi korban pada satu keluarga menunjukkan hasil $6,3 \%$ bentuk unifikasi diturunkan dari ibu ke anak perempuan dan $4,1 \%$ bentuk unifikasi diturunkan dari ayah ke anak laki-laki.27 Perbedaan penurunan bentuk unifikasi dari ayah kepada anak laki-laki dan ibu kepada anak perempuan karena bentuk unifikasi jarang ditemukan pada laki-laki. Hal ini sejalan dengan penelitian Dwivedi (2016) pada 250 lakilaki dan 250 perempuan di India Tengah didapatkan frekuensi bentuk unifikasi lebih banyak sebesar 57,6 pada perempuan dibandingkan frekuensi bentuk unifikasi pada laki-laki.32 Subramanian (2015) melakukan penelitian pada laki-laki dan perempuan didapatkan jumlah rata-rata bentuk unifikasi sebesar 4,2 dan jumlah rata-rata bentuk unifikasi pada perempuan sebesar 11,2.33 Perbedaan bentuk unifikasi pada laki-laki dan perempuan disebabkan karena perbedaan gender. Pada penelitian ini, jumlah ukuran rugae palatina antara mamak dan kamanakan laki-laki tidak memiliki perbedaan yang signifikan $(p>0,05)$. Hal ini sejalan dengan penelitian Hidayani (2016) mengenai pola rugae palatina antara $30 \mathrm{ibu}$ kandung dan anak kandung Suku Minang, menunjukkan ukuran primer, ukuran sekunder, dan ukuran fragmenter memiliki nilai $(p>0,05)$ sehingga tidak terdapat perbedaan yang signifikan pada ukuran rugae palatina.20 Penelitian lain yang sejalan yakni penelitian Kamala (2011) dilakukan pada 50 orang tua dan anak kandung di India menunjukkan nilai 0,99 pada ketiga ukuran yaitu fragmenter, sekunder, dan primer. $^{26}$

Adanya perbedaan dan kesamaan bentuk dan ukuran rugae palatina antara mamak dan kamanakan laki-laki pada hubungan herediter generasi kedua karena penuruan bentuk rugae palatina terjadi melalui mekanisme poligen. ${ }^{13}$ Poligen merupakan gen gen ganda yang dibawa oleh kesamaan DNA dan akan membentuk variasi fenotip yang dominan. Menurut uncle/aunt testing pada hubungan herediter generasi kedua terdapat kesamaan DNA sebanyak $25 \%$. Kesamaan DNA sebanyak 25\% akan 
mempengaruhi variasi fenotip seseorang. ${ }^{13,16}$

Pada pewarisan sifat poligen, satu karakter tunggal fenotip dipengaruhi berbagai macam faktor (multifaktorial). ${ }^{14,56}$ Fenotip merupakan kenampakan bentuk atau sifat yang terlihat pada suatu organisme. Menurut hukum seagregasi Mendel, kombinasi bentuk fenotip yang diturunkan pada hubungan herediter generasi kedua (F2) memiliki kesamaan fenotip dengan perbandingan 3:1. Hal ini yang menyebabkan pada hubungan herediter generasi kedua terdapat sedikit kesamaan bentuk anatomi rugae palatina antara mamak dan kamanakan laki-laki. ${ }^{14,33}$

Poligen yang mempengaruhi fenotip seseorang dipengaruhi oleh berbagai macam faktor, bukan hanya genetik tetapi juga lingkungan. Faktor lingkungan yang mempengaruhi adalah lingkungan prenatal dan postnatal. Pada lingkungan prenatal, mamak dan kamanakan laki-laki memiliki perbedaan karena tidak berasal dari suasana rahim ibu yang sama. Pada lingkungan postnatal mamak dan kamanakan lakilaki suku Minangkabau memiliki kesamaan, seperti kehidupan sosial, ekonomi, pola makan, gaya hidup, dan nutrisi yang dikonsumsi sehingga mempengaruhi cara hidup seseorang. ${ }^{31,23}$
Tidak terdapatnya perbedaan jumlah bentuk dan ukuran rugae palatina secara umum dikarenakan, bentuk dan ukuran rugae palatina sangat dipengaruhi oleh lingkungan yakni kebiasaan pola makan dan makanan yang dikonsumsi. ${ }^{34}$ Pada penelitian ini mamak dan kamanakan laki-laki yang ditemukan banyak berada pada satu rumah sehingga memiliki kesamaan pada makanan yang dikonsumsi. Kesamaan makanan yang dikonsumsi akan mempengaruhi bentuk dan ukuran rugae palatina karena makanan yang dikonsumsi akan menyebabkan perubahan pada jaringan fibrous sehingga mempengaruhi bentuk dan ukuran. ${ }^{34}$ Selain lingkungan prenatal dan postnatal, mamak dan kamanakan laki-laki memiliki kesamaan sexual dimorphism yang menyebabkan kesamaan ukuran rugae palatina. ${ }^{5}$ Sexual dimorphism adalah kesamaan bentuk, ukuran, dan kebiasaan hidup seseorang berdasarkan kesamaan jenis kelamin. Laki-laki biasanya memiliki ukuran bentuk anatomi tubuh seperti bentuk wajah, bentuk kepala, ukuran gigi, ukuran tulang maksila, dan otot tubuh yang lebih besar dibandingkan perempuan. ${ }^{29,35}$

Pada penelitian ini, didapatkan hasil bahwa jumlah bentuk dan ukuran rugae palatina antara mamak dan kamanakan laki-laki memiliki bentuk dan 
ukuran yang mirip tetapi tidak memiliki jumlah yang identik. Kemiripan ini terjadi karena adanya mekanisme poligen yang dibawa melalui kesamaan DNA. Poligen pada variasi fenotip dipengaruhi oleh keadaan lingkungan. Rugae palatina tidak identik pada hubungan herediter karena rugae palatina bersifat unik dan individualistik.

\section{KESIMPULAN}

Pada penelitian ini, didapatkan hasil bahwa bentuk dan ukuran rugae palatina antara mamak dan kamanakan laki-laki memiliki kemiripan tetapi memiliki jumlah yang tidak identik. Kemiripan ini terjadi karena adanya mekanisme poligen yang dibawa melalui kesamaan DNA. Poligen pada variasi fenotip dipengaruhi oleh keadaan lingkungan. Rugae palatina tidak identik pada hubungan herediter karena rugae palatina bersifat unik dan individualistik.31 Penggunaan rugae palatina dalam odontologi forensik dapat digunakan karena pembuatan cetakan gigi rahang atas memiliki beberapa keuntungan yakni waktu pengerjaan cepat, biaya yang terjangkau dan praktis. ${ }^{3,4}$ Pemanfaatan rugae palatina dapat dijadikan salah satu metode sekunder untuk mengidentifikasi seseorang pada bidang odontologi forensik.

\section{KEPUSTAKAAN}

1. B, Kavitha. Einstein, A. Sivapathasundharam, B. Saraswati TR. 2015. Limitations in Forensic Odontology . J Forensic Dent Scie;1(1):8-10

2. Chairani, S. Elza,I Aurkari . 2008. Pemanfaatan Rugae Palatal untuk identifikasi forensik. Indonesian Journal of Dentistry 2008; 15 (3):261-269

3. Saraf, A. S, Bedia. A, Indurkar. S, Degwekar. R, Bhowate. 2011. Ruggae Patterns as an Adjunct to sex differentiation in forensic identification. $\mathrm{J}$ Forensic Odontostomatol 2011;29:1:14-19

4. Rai, Belwant. Jasdeep, Kaur. 2013. Evidance-Based Forensic Dentistry. Ebook.

5. Shetty, D. Achint, Juneja. Anshi, Jain. Khanna, Kaveri. Neha, Pruthi. Meenakshi, Chowdhary. 2015. Assesment of palatal rugae pattern and their reproducibility for application in forensic analysis. J For Dent Scie;5:2:106-109

6. Kapali, S. Townsend ,G. Richards, L. Dan Parish ,T. 1997. Palatal Rugae Patterns in Australian Aborigines and Caucasians. Aust Dent J. 42(2):129-133.

7. Bhaya,Ginia. Arun,Kumar. Shikha,Hamda. Gaurau,Atreja. $\quad$ Ashis,Juneja. 2016. Palatoscopy : A novel tool in human identification. AJOMR;3(1):01-06

8. Mutshubramanian, M. KS, Limson. R, Julian. 2005. Analysis of rugae in burn and victims and cadaver to simulate rugae identificationin cases of incineration and decomposition. J $\quad$ Forensic Odontostomatol;23(1):26-9

9. Mohammed, Rezwana. Rajendra, G. V.R, Pammi. M, Pavvana. Siva, V kalyan. 2015 Rugoscopy: Human identification by computer-assisted photographic superimposition technique. J Forensic Dent Scie;5(2):90-95

10. Akbar, Fahreza. 2014. Perbedaan Pola dan Ukuran Rugae Palatal Ras Deutro Melayu dan Ras Arabik. MMI:1-14.

11. K, Mahsudan. Rajesh N, Patel. Umesh, Sangeeta. Patel, Hiren. 2014. Palatal Rugae Patterns and Its Association with lineage. IJAPBS;3(5):15-19

12. Kochar, Gulsham. Himansu, Duhan. Pretty, Gupta. Rajesh, Gupta. Swati, 
Parhar. Taranjot, Kaur. Comparative analysis of variation in morphology of ruggae pattern among siblings pairs. J Dent Oral Hyg;7(6):91-96

13. Thomaz, CJ. Khotze,TJ. Nash,JM. 1986. The palatal ruga pattern in possible paternity determination. $\mathrm{J}$ Forensic Sci;31(1):288-92.

14. Suryo.2011. Genetika Manusia. Gadjah Mada University Press. Yogyakarta

15. Hardjosubroto,W.1984.AplikasiPemuliaan Ternak di Lapangan. Jakarta:Gramedia

16. Blouin, Michael. 2003. DNA-based methods for pedigree reconstruction and kinship analysis in natural populations. TRENDS in Ecology and Evolution;18(10):503-5011

17. Vats, Yogash. Jasmine, Keur. A.K, Kapoor. 2011. Heritability of Lip Print Patterns among North Indian Populations. J Forensic Res;2(7)

18. Scoot, Richard. Dental antropology. Encyclopedia of Human Biology;2(3): 175-190

19. Sperber, Geofrey. 2015. Teeth,genes, and genealogy.QuintessenceInternational Editorial;46(9):747-749

20. Hidayani,D. 2016. Perbandingan Pola Rugae Palatina pada Mahasiswa Angkatan 2012 dengan Ibu Kandung Suku Minang di FKG Universitas Andalas. Skripsi. Fakultas Kedokteran Gigi Universitas Andalas. Padang

21. Patel, Rajesh,dkk. 2015. Assesing the inheritance of palatal rugae patterns. Int $\mathrm{J}$ of Adv Res;3(6):297-301

22. Indira,AP. Manish, Gupta. Maria, Prisillia. 2012. Usefullness of palatal rugae paterns in estabilishing identity: Premilinary results Bengaluru city, India. $\mathbf{J}$ forensic Dent Scie;4(1):2-5

23. Pratiwi, Dhira. 2016. Perbedaan Rugae Palatal antara Laki-Laki dan Perempuan Suku Minang pada Siswa SMKN 3 Kota Pariaman. Skripsi. Fakultas Kedokteran Gigi Universitas Andalas. Padang

24. Angraini, Eva. 2013. Perbedaan Pola Rugae Palatal pada Penduduk Keturunan Deutro Melayu dan Penduduk Keturunan China di Jawa Tengah. Media Medika Muda. Universitas Dipenogoro.
25. Yatim, Wildan. 1996. Genetika. Edisi 5. Bandung. Penerbit: Tarsito:247-248

26. Kamala, R. Neha, Gupta. Amol, Bansal. Abhisek, Sinha. 2011. Journal of Forensic Dental Sciences. J Indian Acad Oral Med Radiol;23(3):173-178

27. Aditana, Dony. 2014. Perbedaan Pola dan Ukuran Rugae Palatal Ras Deutro Melayu dan Ras Australoid. Media Medika Muda. Universitas Dipenogoro.

28. Muhasilovic, Senad. Naida, Hadziabdic. Ivan, Galic. Marin, Vodanovic. 2016. Analysis of palatal rugae in males and females of an average of 35 in a population from Bosnia and Herzegovina (Sarajevo Canton). J Forensic Leg Med;39:147-150

29. Frayer, David. Milford, Walpoff. 1995. Sexual Dimorphism. Ann Rev.Anthropol;14:429-73

30. Moore, Keith L, Agur, Anne MR. Anatomi Klinis Dasar. Jakarta: Hipokrates; 2002.

31. Chopra, Amaandep. N.C.Rao. Neha Gupta. Shelja Vashitsh. 2015. Palatal Rugae and Arch Length: A Tool in Gender Determination. Univ Res J Dent;3(2):5459

32. Dwivedi, Neha. Anil, Kumar. 2016. Morphological analysis of palatal rugae pattern in central Indian population. J Int Scoc Prev Community Dent;6(5):417-422

33. Subramanian, Pratusha.Nithya Jagannathan.2014. Palatal rugoschopy as a method of sex determination in forensic science.Asian J Pharm Clin Res;8(2):136138

34. Neil, A. Campbell. Jane B. Reece. 2008. Biology. Edisi ke delapan. Penerbit Erlangga:287-288

35. Jibi, Paul. Keshav, K. Nadig, Bassapa.2011. Morphological pattern of palatal rugae in children of devengree. $\mathrm{J}$ Forensic Sci;56(5):1192-1197

36. Samal, Ashok; Subramani, Vanitha; and Marx, David B. 2007. "An Analysis of Sexual Dimorphism in the Human Face". CSE Journal Articles. Paper 95 